\title{
Towards the Development of Collaborative Learning in Virtual Environments
}

\author{
Benjamin Maraza-Quispe ${ }^{1}$, Nicolás Caytuiro-Silva ${ }^{2}$, Eveling Castro-Gutierrez ${ }^{3}$, Melina Alejandro-Oviedo ${ }^{4}$ \\ Walter Choquehuanca-Quispe ${ }^{5}$, Walter Fernandez-Gambarini ${ }^{6}$, Luis Cuadros-Paz ${ }^{7}$, Betsy Cisneros-Chavez ${ }^{8}$ \\ Facultad de Ciencias de la Educación, Universidad Nacional de San Agustín, Arequipa-Perú ${ }^{1,4,5,6,7,8}$ \\ Facultad de Ciencias e Ingenierías Físicas y Formales Universidad Católica de Santa María, Arequipa-Perú2, 3
}

\begin{abstract}
The objective of the research is to evaluate strategies such as Wikis, Forums and Chat in the development of collaborative learning in higher education students. A collaborative experience was developed with 25 students in an asynchronous e-learning environment. The activities consisted of forum discussions, chat and project development in a wiki environment. The research method includes a quantitative analysis whose forum rating was developed by applying a rubric. The use of didactic strategies such as Wikis, Forums and Chat in the learning sessions promotes collaborative learning where the main factors for this to happen are the degree of appropriation of these technologies by students and the mastery of their use by teachers. It is not possible to affirm the superiority of one tool over another because each has its own characteristics and could be used for different purposes, besides having complementary functions, they must organize and complement each other to develop collaborative learning.
\end{abstract}

Keywords-Wikis; forums; chat; learning; collaborative

\section{INTRODUCTION}

"Technological progress, and especially information and communication technologies have influenced many fields, one of which is the education sector" [1], bringing consequently changes from routine learning environments to others characterized by constant transformation and innovation.

The importance and purpose of this research lies in knowing the social and ethical impact of collaborative learning tools and at the same time promote the use of these tools in students because in most cases the teaching-learning processes are carried out routinely, through non-participatory methodologies that directly involve students to develop collaborative processes. The justification for this research lies in the exchange of information, knowledge and dialogues, through active collaboration among team members; allowing self-evaluation and measurement of individual and collective performance, which will facilitate access to a large amount of shared information, as well as the management of such information.

According to [2] "Collaborative Learning consists in learning with others and from others" that is to say, students have the opportunity to be at the center of their own learning, this leads them to determine or plan their objectives, methodology and strategy that promote collaborative learning through a descriptive-experimental study which is analyzed in a sample of 25 students.
A collaborative experience was studied with 25 students in an asynchronous e-learning environment. The activities lasted 24 days and consisted of difficulties in forums, chat and development of a project in a wiki environment. The research method includes a quantitative analysis whose forum rating will be applied in an application based on the following evaluation criteria: (1) Number of entries, (2) Importance of the topic, (3) Contribution of new ideas, (4) quality of interventions and (5) Interaction with peers. The following evaluation criteria will be used to rate the Wikis: (1) Number of entries, (2) Content and quality of contributions, (3) Respect and collaboration, (4) Links and sources and (5) Language management. And to rate the chat, the following evaluation criteria will be used: (1) Language management, (2) Subject mastery, (3) Conventions and (4) Consistency.

\section{STATE OF THE ART}

\section{A. Web 2.0, e-Learning and Moodle}

Web 2.0 [3], is a set of Internet utilities and services that are supported by a database, which can be modified by users of the service. Users can add, change, delete and exchange information, either in the form of presenting them in the content or in both simultaneously. In this context, Web 2.0 combines a variety of learning events with tutorial support to facilitate the transmission of tacit knowledge, [4].

Consequently, Web 2.0 is characterized by the easy management of information, and by promoting a collaborative teaching-learning scheme in which the student is the protagonist of his or her own learning process.

According to [5] currently, the most innovative modality in Web-based distance education are e-Learning systems or environments, which make use of the services and facilities of the Internet, to make the process of collaborative teachinglearning possible; as well as the Web has enabled educational possibilities at certain levels and with very specific applications.

In this context, e-Learning platforms constitute teachinglearning systems mediated by technology, where one of the fundamental requirements is the existence of an Internet connection.

According to [6], Moodle based its design on collaborative learning and ideas of constructivism in pedagogy that assert that knowledge is constructed in the student's mind rather than being transmitted unchanged from books or teachings. 
In this context, Moodle bases its approach on a collaborative learning teaching system, where the student is the center of the process.

\section{B. Moodle Tools}

According to [6], the tools that distinguish the Moodle virtual learning platform are the Forums, Wikis and Chats; [7], classifies the resources available in Moodle into three categories, to which the communication tools can also be added: (a) Transmissive resources, (b) interactive resources, (c) collaborative resources: Moodle includes the following collaborative tools: Forums, Workshops and Wikis [8], cited by [7], (d) In this context collaborative resources are tools oriented to interaction and exchange of ideas, these tools are forums, wikis, workshops, among others, (e) communication tools [8] available in Moodle are: E-mail, Chats, Messages, Consultations and Surveys.

In this context, chats as well as forums and wikis allow interaction and exchange of ideas among participants, creating collaborative learning environments and teamwork, as it allows interaction between teacher-student and student-student at the same time.

\section{Collaborative Learning}

According to [8], collaborative learning enables students to build their own knowledge through a complex interactive process involving three key elements: the students, the content, and the teacher, who acts as facilitator and mediator between the two.

In other words, the student is the active author of the acquisition of his or her own knowledge, through an interactive process in which the content and the teacher are also involved.

According to [9], collaborative learning mediated through ICT tools gives rise to what is known as Computer-Based Collaborative Learning.

According to [10] a constructivist learning environment is based on collaborative learning, a place where students must work together to help each other, using a variety of tools and computing resources that allow the pursuit of learning objectives and activities to solve the problem.

For [11] collaborative learning is based on cognitive theories. In the constructivist theory of [2], learning requires the action of a mediating agent to access the area of proximate development, he will be responsible for setting up a scaffolding that provides security and allows him to appropriate the knowledge and transfer it to his own environment. In the same way, regarding the educational implications of the above [10], it defines teaching as "a continuous process of negotiation of meanings, of establishment of shared mental contexts, fruit and platform, at the same time, of the negotiation process", which allows to verify the connections between learning, interaction and cooperation.

In this context, collaborative learning is another of the constructivist postulates that conceives education as a process of socio-construction in order to know the different perspectives of approaching a given problem, develop tolerance around diversity and the ability to re-elaborate a joint alternative.
According to [11], in order to define a learning environment, it is important to first determine the environment, understanding as environment all that surrounds the teachinglearning process, that is, the space that surrounds the student while participating in said process, constitutes it from material elements such as the infrastructure and facilities of the campus, as well as different factors that directly influence the student such as physical, affective, cultural, political, economic, social, family and even environmental factors; which combine and have a favorable effect or not so much in the student's learning.

In this context, communication between those who are within the teaching-learning process, that is, teacher-students, vice versa, and student-student, measured by the environment that surrounds it and by technologies such as a virtual classroom (CMS Moodle), are environments and factors that often promote the process of collaborative teaching-learning.

\section{Collaborative Learning and Constructivism}

According to [12] collaborative learning is based on cognitive theories.

One of these is the constructivist theory of [2], where the apprentice requires the action of a mediating agent to access the zone of proximate development, this will be responsible for having a scaffolding that provides security and allows that the apprentice appropriates the knowledge and transfers it to his own environment. As for the educational implications.

\section{E. CMS Tools that Contribute to the Development of Collaborative Learning}

According to [12], the Wiki is an instrument that allows everyone to participate in it; they can be visited, edited or changed. The use of this tool begins to gain strength in the academic field in virtual spaces.

On the other hand [13] they affirm that the student is promoted to develop an autonomous learning, in which, under his responsibility he appropriates his formation, exchanging knowledge and ideas with other students, incorporating himself in this way in a collaborative learning. As opposed to what happens in a classroom, the wiki can extend the notes with the collaboration of all; wikis can also be used in parallel with forums or chat.

In this context [5], he affirms that the use of a virtual classroom contributes to improving students' inter-learning; new resources are integrated that help to improve teaching practice, communication, motivation, and orientation; improving the interaction between teacher-student and studentstudent.

Likewise [14] virtual learning environments offer an asynchronous learning space that provides students with course materials, as well as collaboration and interaction during the implementation of a virtual forum.

Some of the benefits of the application [15] of virtual discussion forums: (1) It reinforces learning and improves its significance; (2) It allows students to know their attitudes towards certain topics; (3) It favors the development of social skills through interaction and helps to improve written communication skills. 
For [16] They consider that asynchronous school activities, either through educational platforms CMS promote collaborative work between peers, through the use of forums teachers and students participate on educational topics, interacting with peers, exchanging knowledge, experiences, and expressing their ideas with more freedom and ease, in addition to being able to participate from different geographical locations.

For [17] the objective of a forum is none other than to create reflection, through contributions, to achieve a clear and precise concept, building it little by little, from the contributions of the participants.

Simultaneously [18] emphasizes the potentials of peer collaboration and social negotiation in an asynchronous online environment, individuals are able to build knowledge and relate what they learn to their prior knowledge.

Regarding the rules of courtesy [19], they mention that [...] the forums are regulated by rules of courtesy and that their participants maintain a collaborative and co-evaluative attitude, in order to contrast their points of view, and thus generate a process of knowledge construction.

In this context, the application of virtual spaces, as in the case of virtual forums, which contribute to promoting collaborative learning [20], allow for the strengthening of learning processes in order to reach knowledge.

\section{MATERIALS AND METHODS}

The TISG area (Information Technology in a Global Society) considers people as the central axis around which the TISG study revolves [21], the case studies proposed in the experimentation consider the use of IT (Information technology) and its effects on users.

Participation in the forums, wikis and chats will be evaluated using the headings found in Fig. 1 and in detail described in the following Technical Report ${ }^{~}$.

\section{RESEARCh DESIGN}

\section{A. Sample Population}

The population is made up of 25 randomly selected students who take the TISG course.

As can be seen in Table I.

Two case studies are analyzed: Case A and Case B, where each case corresponds to the issues: IT in the home and leisure,

Modelling and simulations respectively.

Table II shows the heading used to rate student participation in the Forums.

Table III shows the heading used to rate the participation of students in the Chat.

Table IV shows the heading used to rate the participation of students in the Wiki.

\section{ANALYSIS OF RESULTS}

\section{A. Instruments}

The wikis, forums and chat will be implemented under the following criteria and conditions as can be seen in Table V.

As for the data collection instruments, use the Wikis, Forums and Chat, as can be modified in Table V.

TABLE. I. STUdents PaRticipating In the ReSEARCh Phase

\begin{tabular}{|l|l|l|l|}
\hline Case Study & Students & Teachers & Duration \\
\hline A & 25 & 1 & 12 days \\
\hline B & 25 & 1 & 12 days \\
\hline Total participants in A-B cases & 25 & 1 & - \\
\hline
\end{tabular}

TABLE. II. ASSESSMENT RUBRIC-FORUM

\begin{tabular}{|l|l|l|l|l|}
\hline Objectives Criteria & \multicolumn{2}{|l|}{ Excellent (4 points) } \\
\hline Participation & $\begin{array}{l}\text { Participate in the forum with at } \\
\text { least 3 interventions. }\end{array}$ & Very well (3 points). & $\begin{array}{l}\text { Needs improvement (1 point } \\
\text { each item) }\end{array}$ & $\begin{array}{l}\text { Does not (0 points each } \\
\text { item) }\end{array}$ \\
\hline Importance of the topic & $\begin{array}{l}\text { The interventions show, in a } \\
\text { broad way, that he did the } \\
\text { reading and analyzed it based on } \\
\text { the guide. }\end{array}$ & $\begin{array}{l}\text { Participate in the forum with at } \\
\text { least 2 interventions. }\end{array}$ & $\begin{array}{l}\text { Participate in the forum with } \\
\text { at least 1 intervention. }\end{array}$ & $\begin{array}{l}\text { Does not participate in } \\
\text { the forum. }\end{array}$ \\
\hline $\begin{array}{l}\text { Contribution of new } \\
\text { ideas }\end{array}$ & $\begin{array}{l}\text { Provides new ideas and justifies } \\
\text { them (minimum 4 aspects for } \\
\text { Internet planning) }\end{array}$ & $\begin{array}{l}\text { The interventions show that he } \\
\text { did the reading and considered } \\
\text { some of the guiding questions. }\end{array}$ & $\begin{array}{l}\text { Interventions show little } \\
\text { analysis of reading and use } \\
\text { of the guide. }\end{array}$ & $\begin{array}{l}\text { It performs the } \\
\text { intervention but does not } \\
\text { show any analysis of the } \\
\text { reading and the guide. }\end{array}$ \\
\hline Quality of interventions & $\begin{array}{l}\text { The interventions are very clear, } \\
\text { concise and respectful. }\end{array}$ & $\begin{array}{l}\text { Provides new ideas and justifies } \\
\text { them (minimum 2 aspects for } \\
\text { Internet planning). }\end{array}$ & $\begin{array}{l}\text { It provides at least one idea } \\
\text { for Internet planning). }\end{array}$ & $\begin{array}{l}\text { He doesn't bring new } \\
\text { ideas. }\end{array}$ \\
\hline $\begin{array}{l}\text { Interaction with peers } \\
\text { and tutor }\end{array}$ & $\begin{array}{l}\text { Establishes a dialogue with } \\
\text { peers and tutor, debating and } \\
\text { defending ideas, and building } \\
\text { new contributions together. }\end{array}$ & $\begin{array}{l}\text { Interventions are clear, concise } \\
\text { and respectful. }\end{array}$ & $\begin{array}{l}\text { The interventions are } \\
\text { unclear, concise and } \\
\text { respectful. }\end{array}$ & $\begin{array}{l}\text { Interventions are not } \\
\text { clear, concise and } \\
\text { respectful. }\end{array}$ \\
\hline
\end{tabular}


TABLE. III. ASSESSMENT RUBRIC- CHAT

\begin{tabular}{|c|c|c|c|c|}
\hline $\begin{array}{l}\text { Aspects to } \\
\text { evaluate/Performance scales }\end{array}$ & Outstanding & Satisfactory & Needs improvement & Insufficient \\
\hline Language skills & $\begin{array}{l}\text { In his participations, he expresses his ideas } \\
\text { clearly and structurally. }\end{array}$ & $\begin{array}{l}\text { In the participations, he } \\
\text { expresses his ideas with } \\
\text { sufficient clarity. }\end{array}$ & $\begin{array}{l}\text { Some of his ideas are } \\
\text { clear and some are } \\
\text { confusing. }\end{array}$ & $\begin{array}{l}\text { It is not clearly } \\
\text { expressed in its } \\
\text { participations. }\end{array}$ \\
\hline Mastery of the theme & $\begin{array}{l}\text { Shows understanding of the subject and } \\
\text { uses appropriate notation and terminology } \\
\text { to express opinions. }\end{array}$ & $\begin{array}{l}\text { Makes some mistakes in the } \\
\text { terminology used and shows } \\
\text { some gaps in the } \\
\text { understanding of the topic. }\end{array}$ & $\begin{array}{l}\text { He makes many } \\
\text { mistakes in } \\
\text { terminology and shows } \\
\text { deep conceptual gaps. }\end{array}$ & $\begin{array}{l}\text { He shows no } \\
\text { knowledge of the } \\
\text { subject matter. }\end{array}$ \\
\hline Conventions & $\begin{array}{l}\text { Makes good use of the conventions of the } \\
\text { medium: he waits his turn to intervene; he } \\
\text { uses lowercase letters when he writes (he } \\
\text { does not "shout" in capital letters); he is } \\
\text { respectful of the opinions of his peers; he } \\
\text { expresses ideas briefly; he uses polite } \\
\text { language; he uses contrasting color for his } \\
\text { interventions; he uses emoticons. }\end{array}$ & $\begin{array}{l}\text { It uses most of the } \\
\text { conventions of the medium. }\end{array}$ & $\begin{array}{l}\text { Use some of the } \\
\text { conventions of the } \\
\text { medium. }\end{array}$ & $\begin{array}{l}\text { Use few or none of } \\
\text { the conventions of } \\
\text { the medium. }\end{array}$ \\
\hline Coherence & $\begin{array}{l}\text { Listen (read) carefully to what others } \\
\text { contribute and follow the thread of the } \\
\text { conversation with congruent comments. }\end{array}$ & $\begin{array}{l}\text { In general, your comments } \\
\text { are accurate and respect the } \\
\text { main topic of the chat. }\end{array}$ & $\begin{array}{l}\text { Some comments } \\
\text { deviate from the theme. }\end{array}$ & $\begin{array}{l}\text { He makes trivial and } \\
\text { off-topic comments. }\end{array}$ \\
\hline
\end{tabular}

TABLE. IV. ASSESSMENT RUBRIC - WIKI

\begin{tabular}{|c|c|c|c|c|}
\hline $\begin{array}{l}\text { Aspects to evaluate / } \\
\text { Performance scale }\end{array}$ & Outstanding & Satisfactory & Needs improvement & Insufficient \\
\hline Participation & $\begin{array}{l}\text { Edit an existing article or create a } \\
\text { new one, with formatting and } \\
\text { images. }\end{array}$ & $\begin{array}{l}\text { Edit an existing article or } \\
\text { create a new one. }\end{array}$ & $\begin{array}{l}\text { You have a lot of difficulty } \\
\text { editing an existing article or } \\
\text { creating a new one. }\end{array}$ & $\begin{array}{l}\text { You cannot edit or create an } \\
\text { article. }\end{array}$ \\
\hline $\begin{array}{l}\text { Content and quality } \\
\text { of contributions }\end{array}$ & $\begin{array}{l}\text { In their contributions, they } \\
\text { express extensive knowledge on } \\
\text { the subject and integrate useful } \\
\text { information and knowledge that } \\
\text { enrich the text. He presents } \\
\text { arguments and his ideas are clear } \\
\text { and profound. }\end{array}$ & $\begin{array}{l}\text { In their contributions, they } \\
\text { demonstrate knowledge about } \\
\text { the subject and integrate } \\
\text { certain information and } \\
\text { knowledge that help to enrich } \\
\text { the text. Most of his ideas are } \\
\text { clear and he argues for them. }\end{array}$ & $\begin{array}{l}\text { Their contributions } \\
\text { demonstrate vague } \\
\text { knowledge on the subject } \\
\text { and integrate information or } \\
\text { knowledge with difficulty. } \\
\text { Few of their ideas are clear. }\end{array}$ & $\begin{array}{l}\text { Your contributions demonstrate } \\
\text { that you have no knowledge of } \\
\text { the subject and do not integrate } \\
\text { additional data or information. } \\
\text { Ideas are confusing and } \\
\text { superficial. Expresses only } \\
\text { opinions and does not argue. }\end{array}$ \\
\hline $\begin{array}{l}\text { Respect and } \\
\text { collaboration }\end{array}$ & $\begin{array}{l}\text { He collaborates in a respectful } \\
\text { way in his participations and in } \\
\text { case of disagreement, he resorts } \\
\text { to dialogue. }\end{array}$ & $\begin{array}{l}\text { Collaborate respectfully but, } \\
\text { in case of disagreement, avoid } \\
\text { conflict or respond with little } \\
\text { self-criticism. }\end{array}$ & $\begin{array}{l}\text { Sometimes he is not } \\
\text { respectful with the rest of } \\
\text { the collaborators and can } \\
\text { respond aggressively. }\end{array}$ & $\begin{array}{l}\text { He is not respectful in his } \\
\text { contributions or responses to } \\
\text { other collaborators. Does not } \\
\text { accept criticism and is not } \\
\text { capable of constructing a group } \\
\text { text. }\end{array}$ \\
\hline Links and sources & $\begin{array}{l}\text { The article created or the } \\
\text { contribution made has at least } \\
\text { two links that work or at least } \\
\text { two sources of its arguments } \\
\text { completely. }\end{array}$ & $\begin{array}{l}\text { The article created or the } \\
\text { contribution made has a link } \\
\text { that works or cites a source of } \\
\text { its arguments in a complete } \\
\text { way. }\end{array}$ & $\begin{array}{l}\text { The article created or the } \\
\text { contribution made has a } \\
\text { link that does not work or in } \\
\text { the contribution cites the } \\
\text { sources of its arguments } \\
\text { incompletely. }\end{array}$ & $\begin{array}{l}\text { The article created or the } \\
\text { contribution made has no links or } \\
\text { quotations, and no reference to } \\
\text { sources. }\end{array}$ \\
\hline Language skills & $\begin{array}{l}\text { In his participations he expresses } \\
\text { his ideas with total clarity and } \\
\text { structuring; he applies correctly } \\
\text { the orthographic, grammatical } \\
\text { and syntax rules. }\end{array}$ & $\begin{array}{l}\text { In his participations, he } \\
\text { expresses ideas with sufficient } \\
\text { clarity; in most cases, he } \\
\text { applies the rules of spelling, } \\
\text { grammar and syntax correctly. }\end{array}$ & $\begin{array}{l}\text { In his participations, he } \\
\text { does not express ideas } \\
\text { clearly and applies the rules } \\
\text { of spelling, grammar and } \\
\text { syntax, with errors. }\end{array}$ & $\begin{array}{l}\text { He does not express himself } \\
\text { clearly in his participations; } \\
\text { apply them to orthographic, } \\
\text { grammatical and syntax rules, } \\
\text { with many errors. }\end{array}$ \\
\hline
\end{tabular}

TABLE. V. DATA COLLECTION INSTRUMENTS

\begin{tabular}{|c|c|c|c|}
\hline \multirow{3}{*}{ forums } & News forum & \multirow{3}{*}{ A Case Study } & \multirow{3}{*}{$\begin{array}{l}\text { The number of units and contributions made measures it. } \\
\text { Forums are evaluated according to the evaluation rubric. }\end{array}$} \\
\hline & Forum questions and discussion of the case study & & \\
\hline & Forum to discuss any topic & & \\
\hline \multirow{3}{*}{ wikis } & Wiki News & \multirow{3}{*}{ Case Study B } & \multirow{3}{*}{$\begin{array}{l}\text { The number of units and contributions made measures it. } \\
\text { Wikis are evaluated according to the evaluation rubric. }\end{array}$} \\
\hline & Wiki doubts and debate the case study & & \\
\hline & Wiki to discuss any topic & & \\
\hline Chat & General: & It applies to both cases & $\begin{array}{l}\text { It is measured by the number of units and inputs, and was } \\
\text { evaluated according to the column. }\end{array}$ \\
\hline
\end{tabular}




\section{OBTAINING AND ANALYZING RESUlTS}

A previous study was carried out to obtain data on the tools in both Case Studies (CS), and then to make the comparison, see Fig. 1

\section{A. Comparison of Number of Shares Forum Case Study A and $B$}

In the graph in CS-A, two students have a total of 06 participations, representing 6\%, while four students only participated once, representing $3 \%$ of the total number of students. Similarly, in CS-B, two students have a total of 06 and 05 participations, while 08 students have an average between 03 and 04 participations.

On the basis of the results obtained we can analyze that in the forum of the CS-B, a smaller number of participations is presented, however, the quality of interventions has improved considerably with respect to the CS-A, this because the students were already familiar with the use and functionality of the forums.

\section{B. Comparison of the Average of Ratings According to the Evaluation Rubric of Forum CS - A and B, see Fig. 2}

In the CS - A, with respect to the average grades by criterion according to the rubric, it can be observed that the highest average belongs to the participation criterion; while the lowest average corresponds to the criterion of interaction with peers and tutor. In the sense it can be inferred that students participate actively, however, it is at a basic level of collaboration and the quality of interventions with peers and tutor is poor.

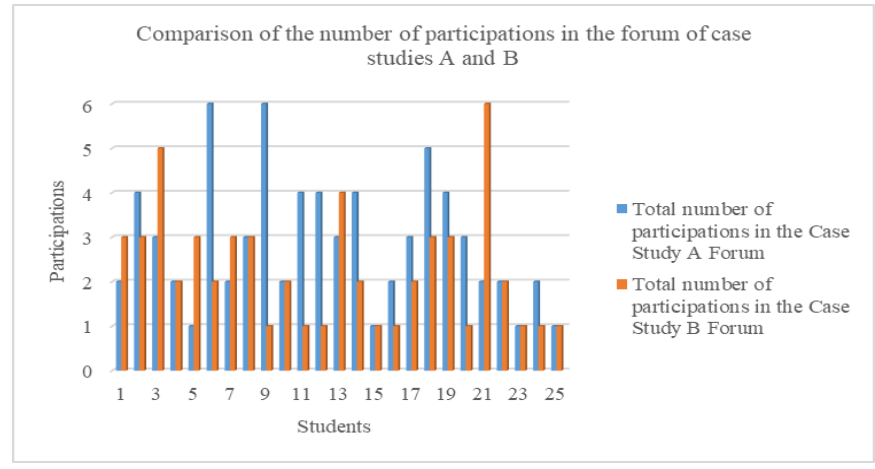

Fig. 1. Comparison of Number of Shares Case Study forum A and B.

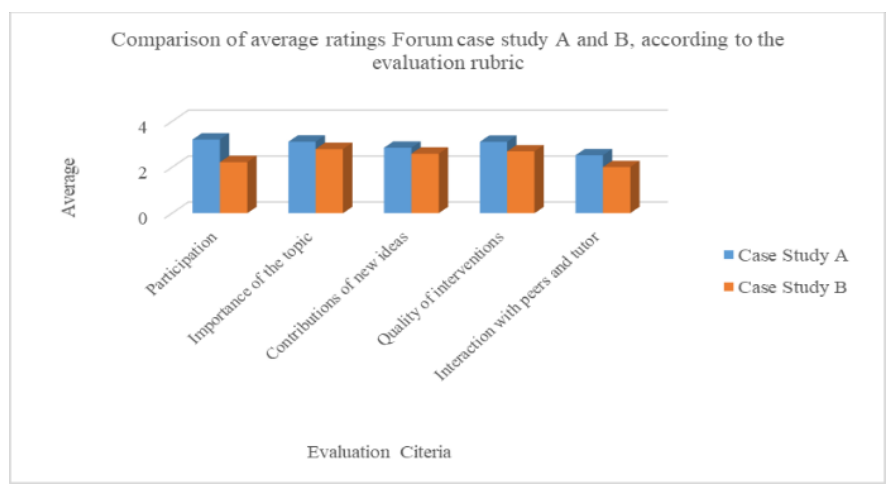

Fig. 2. Comparison of the Grade Point Average According to the Evaluation Rubric.
While in CS-B, the quality of the interventions and the importance of the topic present a higher average than the weighted average, so it can be interpreted that the forums are used to build quality knowledge from the contributions of other peers, regardless of the number of interventions.

\section{Comparison of the Number of Wiki, CS - A and B Participations, see Fig. 3}

In CS-A, the results show that students are familiar with participation through the wiki tool, since most participations range from 3 to 4 participations, which shows that there is participation and collaboration on the part of the students. Similarly, in CS-B the results show that students are familiar with participation through the wiki tool, since most participations range from 5 to 4 participations, which shows that there is student participation and collaboration.

\section{Comparison of Average Ratings According to the Wiki \\ Evaluation Rubric Case study A and B, see Fig. 4}

In the CS - A the content and quality of participations, the respect and collaboration on the part of the students represent a superior average to the weighted average, reason why we can interpret that the wikis help the students to make good contributions fomenting the respect and collaboration with theirs. In the same way in the CS - B the content and quality of participations, links and sources, represent a higher average than the weighted average, so it can be said that wikis help students to develop better skills such as research and analysis and interpretation of the sources consulted to support their ideas.

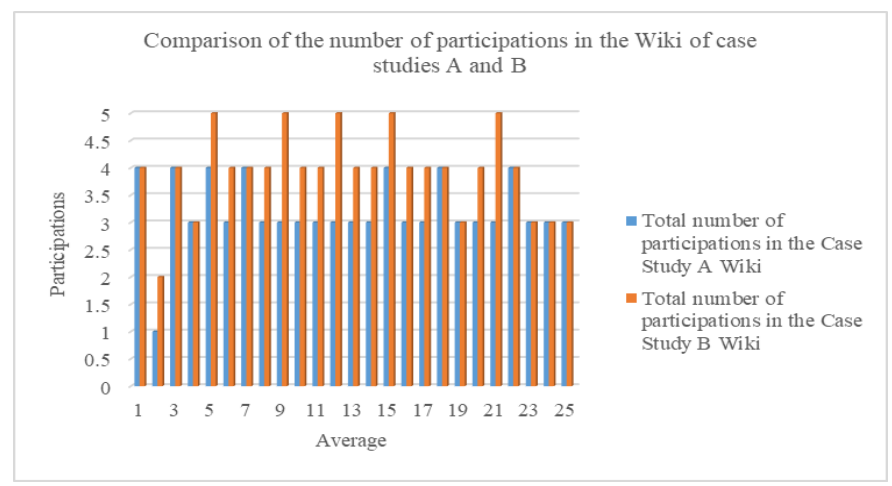

Fig. 3. Comparison of the Number of CS - A and B Wiki Participations.

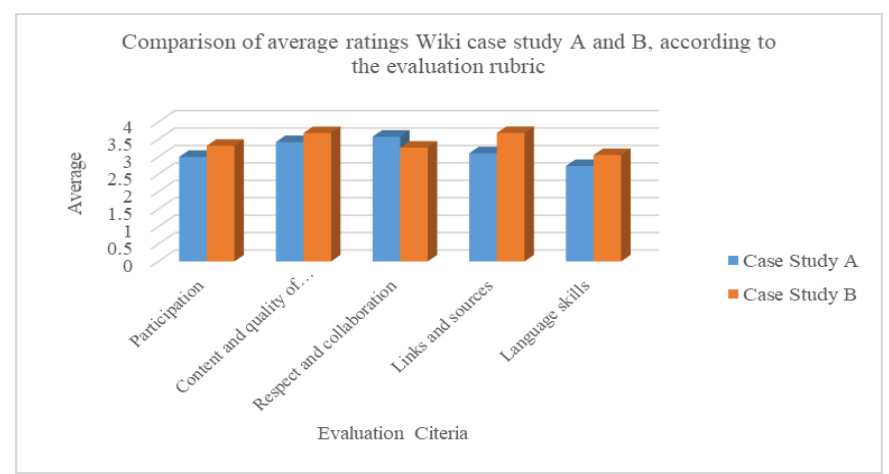

Fig. 4. Comparison of the Average of Ratings According to the Evaluation Rubric of Forum CS - A and B. 


\section{E. Comparison of the Number of Shares Chat Case study A} and $B$, see Fig. 5

In both Case Studies, students are familiar with participation through the chat tool, since most participations range from 4, 5 to 6 participations, demonstrating that student collaboration and participation has developed significantly.

\section{F. Comparison of the Average of Ratings According to the} Chat Evaluation Rubric Case Study A and B, see Fig. 6

From the case of Study B we can analyze that the domain of the subject on the part of the students and the conventions used by these, represent a superior average to the weighted average, reason why we can interpret that the chat, encourages the students to that these read more on the subject, have a greater domain on the subject and be respectful with their other companions. While in Case Study A, the conventions of the medium are used correctly: it waits its turn to intervene; it uses lowercase letters when it writes, and so on. This represents a higher average than the weighted average, so we can interpret that chat helps students to be respectful and develop assertive communication.

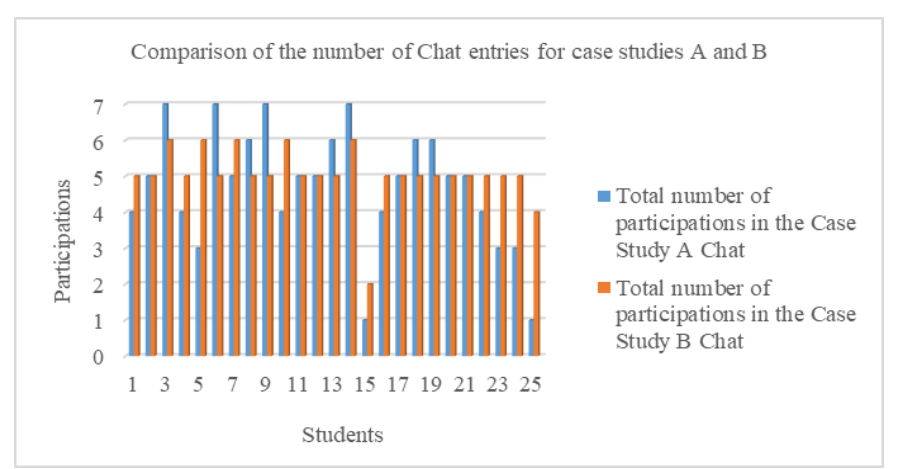

Fig. 5. Comparison of the Number of Shares Chat Case Study A and B.

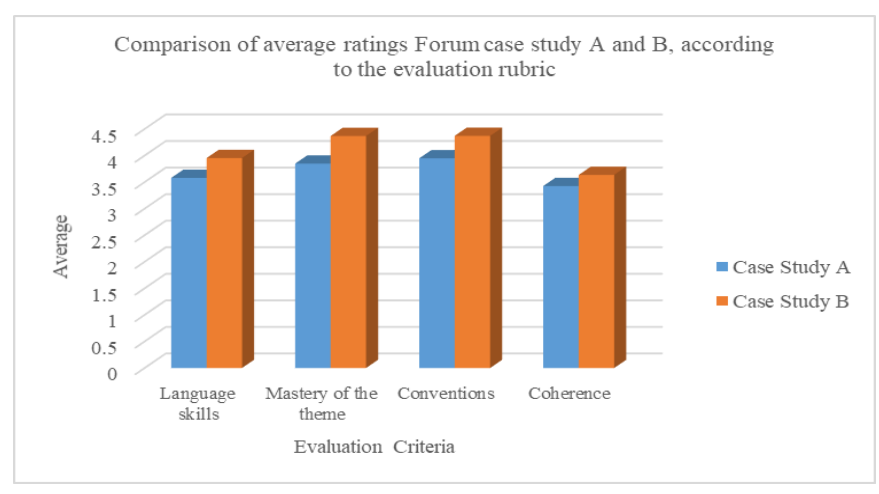

Fig. 6. Comparison of the Grade Point Average According to the Chat Evaluation Rubric Case Study A and B.

\section{DISCUSSION}

It is not possible to affirm the superiority of one tool over another because each one has its own characteristics and could be used for different purposes. The forums, wikis and chat could have complementary functions and should be organized to complement each other to develop collaborative learning. The digital divide for the use of these technologies can cause students who do not have access to them to be disadvantaged

\section{CONCLUSIONS}

From the evidence shown in the investigation, one can conclude:

- The use of didactic strategies such as Wikis, Forums and Chat in the sessions promote collaborative learning. The main factors for this to happen are the degree of appropriation of these technologies by students and the mastery of their use by teachers.

- The digital divide for the use of these technologies can cause students who do not have access to IT to be disadvantaged.

- Wikis, Forums and Chat encourage and enhance students' reflection on their own practice, in an interactive way, encouraging critical analysis and autonomous and collaborative work.

- The experimentation carried out is useful not only for students, but for all teachers who want to promote collaborative learning.

- Some doubts or topics are difficult to address from chat sessions, for this we use the forums that are the most appropriate to develop collaborative learning.

\section{FUTURE WORKS}

It is necessary to use learning analytics in order to use the information collected and the analysis and reporting of data on students and their contexts, in order to understand and optimize learning and the environments in which it occurs.1 A closely related field is educational data mining.

\section{REFERENCES}

[1] L. Emiro, C. Bravo, and F. D. P. Santander, "Incorporación de las TIC en procesos Industriales," vol. 7, pp. 11-23, 2016.

[2] L. Vigotsky, "Internalizacion de las funciones psicologicas superiores.," El Desarro. los procesos psicológicos Super., pp. 87-116, 1978.

[3] F. X. Ribes Guardia, "La Web 2.0. El valor de los metadatos y de la inteligencia colectiva," Telos Cuad. Comun. Tecnol. y Soc., no. 73, pp. 0036-0043, 2017.

[4] C. F. M. Tamayo, "Universidad Complutense de Madrid Plataformas Virtuales Como Recurso para la Enseñanza en la Universidad: Análisis, Evaluación y Propuesta de Evaristo Alejandro Nafría López,” 2016. 
[5] Gómez García Melchor, Estudio teórico, desarrollo, implementación y evaluación de un entorno de enseñanza colaborativa con soporte informático (CCCL) Para matemáticas. 2016.

[6] J. Cabrera, "Creación de un aula virtual en la Plataforma Moodle como complemento en el interaprendizaje de la informática de los jóvenes de la Unidad Educativa Salesiana Domingo Savio de Cayambe”. 2017.

[7] E. Jay, M.; Pérez, "Plataforma virtual Moodle y su incidencia en la calidad del proceso de enseñanza aprendizaje de estudiantes universitario," VI Congr. Virtual Iberoam. Calid. en Educ. Virtual y a Distancia, 2015.

[8] María García, "Análisis del desarrollo de extensiones para Moodle: Desarrollo de un módulo para la gestión de laboratorios docentes," 2015.

[9] Gómez García Melchor, Estudio teórico, desarrollo, implementación y evaluación de un entorno de enseñanza colaborativa con soporte informático (cscl) Para matemáticas. 2016.

[10] V. Álvares, “Aprendizaje colaborativo mediado por TIC en la enseñanza universitaria: un acercamiento a las percepciones y experiencias de profesores y estudiantes de la Universidad Autónoma de Chihuahua," Univ. Salamanca, 2016.

[11] M. E. Calzadilla, “Aprendizaje Colaborativo y TIC," Rev. Iberiamericana Educ., vol. 1, no. ISSN: 1681-5653, pp. 1-10, 2014.

[12] Marianella Castro; María Morales, "Los ambientes de aula que promueven el aprendizaje, desde la perspectiva de los niños y niñas escolares," 2015.
[13] D. A. Padilla Beltrán, José E; Vega Rojas, Paula L; Rincón Caballero, "Revista Academia y Virtualidad Revista Academia y Virtualidad," Acad. y Virtualidad, vol. 6, no. 1, pp. 34-55, 2015.

[14] L. G. Aretio and E. Bened, "Wiki en contextos educativos," Uned, 2016.

[15] N. K. Subramaniam and M. Kandasamy, "The virtual classroom: A catalyst for institutional transformation," Australas. J. Educ. Technol., vol. 27, no. 8, pp. 1388-1412, 2017.

[16] D. Ornelas, "El uso del Foro de Discusión Virtual en la enseñanza," Rev. Iberoam. Educ., vol. 44, 2007.

[17] M. Lima, J. Villarruel, and R. Rivera, "La utilidad del foro virtual para el aprendizaje colaborativo, desde la opinión de los estudiantes," Campus Virtuales, vol. 5, no. 2, pp. 122-133, 2016.

[18] V. Cuenca, "El foro virtual como estrategia de enseñanza en la educación superior," vol. 2, no. 1, pp. 23-31, 2015.

[19] J. Abawajy, "Analysis of Asynchronous Online Discussion Forums for Collaborative Learning," Int. J. Educ. Learn., vol. 1, no. 2, pp. 11-22, 2017.

[20] A. Arbey Sánchez-Upegui, "Investigación Pedagógica New Modes of Educational Interaction: Linguistic Analysis of a Virtual Forum Novos modos de interação educativa: análise lingüística de um foro virtual," vol. 12, no. 2, pp. 29-46, 2015.

[21] B. Garibay, M.; Concari, S; Ordóñez, "Desarrollo del aprendizaje colaborativo empleando tareas mediadas por foros virtuales," vol. ii, 2016. 